\title{
EVALUATION OF BOTANICAL EXTRACTS AGAINST Callosobruchus maculatus F. (COLEOPTERA: CHRYSOMELIDAE) ON DIFFERENT HOST GRAINS
}

\author{
Niranjana R F*, Karunakaran S \\ Department of Agricultural Biology, Faculty of Agriculture, Eastern University, Sri Lanka
}

\begin{abstract}
As the damage of stored legume grains by Callosobruchus maculatusis severe in Sri Lanka, the present study was conducted to find the remedial solution for this existing problem. The experiment was designed to select the most effective botanical insecticides; Azadirachta indica 10 $\%$, Vitex negundo10 \%, Eucalyptus globulus $10 \%$, Annona squamosal $10 \%$ and Allium sativum $10 \%$ against the insect pest, Callosobruchus maculatus (bruchid beetle) on stored grains; Vigna unguiculata var. Waruni (red cowpea), Vigna unguiculata var. Dhawala (cowpea with black eye), Vigna radiate (green gram) and Cicer arietinum (chickpea). Among these treatments, A. indica 10 $\%$ and $A$. sativum $10 \%$ were found to be the significantly best along with $80 \%$ of mortality in adult weevils and zero damaged seeds in all treated grains whereas V. negundo $10 \%$ and E. globulus $10 \%$ had average mortality effect (40-50\%) at the beginning of the study. Apart from this zero seed, damage was observed in chickpea treated with all treatments including untreated control. The study showed the non-preference of chickpea by C. maculatus as the seed coating was resistant to the beetle attack.
\end{abstract}

Keywords: Allium sativum, Azadirachta indica, Botanical insecticides, Callosobruchus maculatus, mortality, stored grains

*Corresponding author: niranjanaf@esn.ac.lk

(iD https://orcid.org/0000-0002-4272-4870 


\subsection{INTRODUCTION}

Legume grains are the main food of one-third of the world's poorest people in Africa and Southeast Asia [1]. These grains play the major role in the income of farmers as well as the nutritional status and diet of people of these regions including Sri Lanka. These are high in protein contents and can be consumed directly or as flour, sprouts, etc. It can also be used during weaning food for young children thus ameliorating malnourishment [2]. Every year farmers for their future needs store a certain amount of the total grain production. It is important that the harvested seeds have to be stored for about 7-9 months until the next planting seasons [3]. However, post-harvest losses of legume grains are a serious problem due to damage caused by insect, $C$. maculatus, Tribolium castaneum, Sitophilus oryzae, S. zeamais, Sototroga cerealella etc. Huge losses between 20 and 50 $\%$ have been reported in stored grains due to attack by cowpea beetle, Callosobruchus maculatus and sometimes the loss may go up to $100 \%$ [4]. It was reported that the grains such as cowpea, chickpea, Bambara groundnut, green gram, lentil, broad bean and green pea were the hosts of larvae of $C$. maculates $[5,6]$.

The damage is distinctive; larvae feed and develop inside the seed. Each larvae consumes approximately $25 \%$ of the seed from which it develops and results in loss of quality and mould growth [7]. Further, as the larvae bore into the pulse grains, make the seeds unsuitable for human consumption and, replanting due to loss of viability and production of sprouts [8]. Thus, farmers are forced to sell their products early after harvest when prices are still low partly because of anticipated losses in storage [9].

A commonly used method of controlling insect pests of stored products is the application of synthetic contact insecticides and fumigants [10]. The indiscriminate use of broad-spectrum insecticides has created more problems than resolving them. The development of pesticide resistance by the pests, toxic residues in food and consequent health hazards, destruction of beneficial organisms, rapid resurgence of target pest populations and undesirable environmental pollution are critical problems that have arisen by the indiscriminate use of insecticides at storage [11].

It is well aware that the loss to stored products by the cowpea beetle is severe in worldwide including Sri Lanka and the hazardous effects of synthetic insecticide is much serious. Now there is an urgent need for the management practices, which are less toxic to human and environment. The past studies revealed that the pesticide plants have been in nature as its component for millions of years without any ill or adverse effect on the ecosystem $[12,13]$. In addition, as the plant-based pesticides are renewable in nature, cheaper, very slow development of resistance in insect pest, etc. occupied a remarkable place in pest management [14]. Thus, now the era in insect pest management switched on towards pesticide plants, which are safer and recorded with no any ill effects to the ecosystem. As the plants, neem (Azadirachta indica), nochi (Vitex negundo), eucalyptus (Eucalyptus globulus) and annona (Annona squamosa) and the garlic bulbare easy to collect at the Eastern region of the Sri Lanka and their insecticidal properties are being tested against the management of various insect pests, the present study was undertaken to find the efficacy of these selected botanical insecticides against cowpea weevil, which is the most serious pest of stored products in Sri Lanka [15]. 


\subsection{MATERIALS AND METHODS}

The present study focused on the efficacy of fresh leaf extracts of different plants viz., neem $10 \%$ (Azadirachta indica), nochi $10 \%$ (Vitex negundo), eucalyptus $10 \%$ (Eucalyptus globulus), annona $10 \%$ (Annona squamosa) as well as extracts of bulbs of garlic $10 \%$ (Allium sativum) against the insect pest, Callosobruchus maculatus of four stored grains; red cowpea (Vigna unguiculata var. Waruni), cowpea with black eye (Vigna unguiculata var. Dhawala), green gram (Vigna radiata) and chickpea (Cicer arietinum). The experiment was conducted in the laboratory of the Department of Agricultural Biology, Eastern University of Sri Lanka during the season Yala 2017 (June-August 2017).

\subsection{Preparation of botanical insecticides}

\section{a. Leaf extracts}

The method described by Gayatri and Rajani, (2017) [16] was slightly modified to prepare aqueous plant leaf extracts. Fresh and matured mixture of mid and lower leaves of neem, nochchi, eucalyptus, and annona were separately collected from Agronomy farm, Faculty of Agriculture, Eastern University, Sri Lanka and brought immediately to the laboratory. One kilogram from each of the varietals' leaves was ground by using a domestic electric grinder and mixed them with one liter of water. Mud pots with the leaves solutions were buried in soil for 7 days. The properly soaked solution was strained and used as the treatment after diluting it in water for 1:10 ratio [17]. The methodology for leaf extraction was repeated prior to each application.

\section{b. Garlic bulb extracts}

The methodology by Suleria and co-authors (2012) [18] was slightly modified for the preparation of aqueous garlic bulb extract. Finely ground two hundred and fifty grams of dried garlic was mixed with one liter of water and the solution was poured in a mud pot and buried in soil for 7 days. Then the solution was filtered and diluted 1:10[17] and used for experiments.

\subsection{Mass rearing of $C$. maculatus}

Adult insects of cowpea beetle were collected from the laboratory cultures and local market at the Batticaloa district and confirmed the species as $C$. maculatus. The collected insects were mass reared by adapting the methodology stated by Abdullah et al. (2017) [19]. Cleaned and well-sieved cowpea seeds were obtained from Agronomy Farm, Eastern University of Sri Lanka, Vantharumoolai. Five hundred grams cowpea seeds were taken separately into two sterilized polymate plastic insect cages with the capacity $20 \mathrm{~cm} x 6 \mathrm{~cm} x 15 \mathrm{~cm}$. About 100 male and female adults of cowpea beetles were added into each cage and covered by muslin cloths by tying them by rubber bands to prevent the weevils from getting out or in. Then the cages were placed at $30^{\circ} \mathrm{C} \pm 2.0$ and $75 \pm 5.0 \%$ RH. After a week, the insects were sieved out and discarded, and the cowpea seeds with eggs of cowpea beetle were kept for about 4 weeks until the emergence of adult insects. Two to four days old, adult insects were used for the experiments. 


\section{Experimental setup}

The efficacy of botanical insecticides viz., leaf extracts of neem, anona, nochchi, and eucalyptus and bulb extracts of garlic were evaluated against $C$. maculatus on different hosts viz., Red Cowpea, Cowpea with black eye, Green gram and Chick pea. All the treatments were arranged in Complete Randomized Design along with four replications at the laboratory of the Department of Agricultural Biology, Eastern University, Sri Lanka.

\section{Application of treatments}

Two thousand and four hundred grams of seeds from each variety namely, red cowpea, white cowpea, green gram and chickpea were taken and thoroughly cleaned and exposed in an oven dried under the condition of $60^{\circ} \mathrm{C}$ for about 6 hours to ensure the absence of insects, mites and disease causing microorganisms.

The sterilized seeds of one variety were divided into six seed lots each containing four hundred grams of seeds. Each seed lot was separately treated with each of the diluted botanical solution viz., leaf extracts of neem $10 \%$, anona $10 \%$, nochi $10 \%$, and eucalyptus $10 \%$ and bulb extracts of garlic $10 \%$ and untreated control. $100 \mathrm{ml}$ of each of the botanical pesticide was taken in a hand sprayer and sprayed evenly over the respective seed lot until all the seeds were wetted. Similarly, water was sprayed to the untreated control treatment. The treated seed lots were air-dried under shaded condition. Likewise, other seed varieties were treated.

In order to set the replications, each seed lot consisting four hundred grams of seeds of one variety was further grouped into four as one contained one hundred grams of grains. Each $100 \mathrm{~g}$ seed lot was kept in a gunny bag and five pairs of male and female cowpea beetle were introduced into each bag. After the introduction of stored pest, the gunny bags containing treated and untreated seeds were tightly tied to prevent the movement of insects from inside to outside or vice versa.

Similar manner all treatments and replications were designed and kept in the laboratory. In order to increase the efficacy of botanical insecticides the second application was made at 2 weeks after $1^{\text {st }}$ application. At the time of second application of botanical insecticides to the respective seed lots, the live beetles were removed carefully and after drying of insecticides the beetles were replaced in the seed lot and gunny bags were tied. The dead insects and damaged grains, with exiting holes of adult bruchid beetles were counted in weekly interval after the first and second application of botanical pesticides to the respective seed lots.

\subsection{Data Analysis}

The data collected were subjected to PROC MIXED in SAS 9.1 (two-factor ANOVA). Multiple comparisons were done on least square means using DMRT. All the comparisons were considered significant when $\mathrm{p}<0.05$. 


\subsection{Results and Discussion}

Five indigenous plants leaf extracts and untreated control were evaluated against cowpea beetle on stored grains; red cowpea (Vigna unguiculata var. Waruni), cowpea with black eye (Vigna unguiculata var. Dhawala), green gram (Vigna radiate) and chickpea (Cicer arietinum). The results of this experiment conducted during the period Yala 2017 (June-August 2017) is presented and discussed below.

\section{Mortality Rate of adult Callosobruchus maculatus}

The percentage mortalities of $C$. maculatus exposed to different treatments are given in Table 1 . Results revealed that $100 \%$ of mortality in almost all the treatments in chickpea except un-treated control at 7 days after $1^{\text {st }}$ spray whereas since 14 DAS $100 \%$ of mortality was noted in all treatments of chickpea including un-treated control. The findings of present study showed that the mortality of cowpea beetles at the treated and non-treated chickpea due to the effect of insecticide as well as seed characteristics of chickpea, which was evidenced with the statement of Muhammad Sarwar (2012) that the tolerant varieties of chickpea that exhibited hard and wrinkled seed coat lead to harmful relation with pest appearance and grain damage, and these characteristics of chickpea had a negative relation with pest manifestation [20]. Further, it was noted that, the chickpea genotypes with wrinkled seed coat and black colour had affected beetle development and seemed to be less preferred than smooth, plumpy and white colour seeds of chickpea cultivars [21]. In addition, a study stated that the female bruchids usually oviposits on the smooth side of a bean rather than the rough top and it avoids legumes without any smooth surface [22]. The bruchid weevil would choose its host depending on the variety and size of the bean as well as texture of the seeds [23]. In contrast, in few studies it was pointed out that the chickpea (Cicer spp.) was the host of cowpea bruchids $(C$. maculatus) $[5,20]$. Based on these discussions and results of the present study, it can be concluded that chickpea was not the host of cowpea bruchids.

Apart from this finding, almost all the tested botanical pesticides reduced the survival of $C$. maculatus in all tested hosts. However, the study proved the superiority of garlic $10 \%$ in controlling the cowpea weevil especially in green gram (88.9 \%) followed by cowpea with black eye $(80.9 \%)$ and red cowpea $(80 \%)$ at 7 day after first spray. At the same time neem $10 \%$ also exhibited $80 \%$ of bruchid mortality in green gram, cowpea with black eye and red cowpea. However, $100 \%$ of bruchid mortality was reached in garlic $10 \%$ and neem $10 \%$ treated grains after 14 day of first treatment. Meanwhile, significantly very low mortality (10\%) revealed in green gram, cowpea with black eye and red cowpea treated with annona. The garlic $10 \%$ and neem $10 \%$ were considered as better treatment than other botanicals according to the results of the present study. Though annona $10 \%$, nochi $10 \%$ and eucalyptus $10 \%$ were recorded with significantly low mortality than garlic $10 \%$ and neem $10 \%$ at the beginning of experiment, they destroyed almost all the insects after second treatment in all tested hosts.

A study by Bamphitlhi Tiroesele (2015) [24] stated $87.5 \%$ of mortality in C. maculatus on in Vigna subterranea treated with $0.55 \mathrm{gm}$ of chopped garlic per $50 \mathrm{gm}$ of grains, and this finding supports the present study results. Certain studies revealed a positive response against brichid beetles by the application of African nutmeg, clove and garlic [25], and chili pepper and black pepper [26]. 
Table 1: Percentage mortality of adult cowpea beetles (Callosobruchus maculatus) by the application of botanical insecticides on different host grains
Hosts
Treatments
Percentage of Mortality*

$1^{\text {st }}$ Spray $\quad 2^{\text {nd }}$ Spray

\begin{tabular}{cccc}
\hline $\begin{array}{c}\text { Days after } \\
\text { spray }\end{array}$ & $\begin{array}{c}14 \text { days after } \\
\text { spray }\end{array}$ & $\begin{array}{c}7 \text { Days after } \\
\text { spray }\end{array}$ & $\begin{array}{c}14 \text { days after } \\
\text { spray }\end{array}$
\end{tabular}

\begin{tabular}{|c|c|c|c|c|c|}
\hline \multirow{6}{*}{$\begin{array}{l}\text { Red Cowpea } \\
\text { (Vigna } \\
\text { unguiculata } \\
\text { Var: Waruni) }\end{array}$} & Neem & $80.0(63.4)^{c}$ & $100.0(90.0)^{\mathrm{a}}$ & $100.0(90.0)^{\mathrm{a}}$ & $100.0(90.0)^{\mathrm{a}}$ \\
\hline & Eucalyptus & $30.0(33.2)^{\mathrm{g}}$ & $80.0(63.4)^{b}$ & $100.0(90.0)^{\mathrm{a}}$ & $100.0(90.0)^{\mathrm{a}}$ \\
\hline & Nochi & $50.0(45.0)^{\mathrm{e}}$ & $80.0(63.4)^{b}$ & $100.0(90.0)^{\mathrm{a}}$ & $100.0(90.0)^{\mathrm{a}}$ \\
\hline & Annona & $10.0(18.4)^{h}$ & $80.7(63.4)^{b}$ & $100.0(90.0)^{\mathrm{a}}$ & $100.0(90.0)^{\mathrm{a}}$ \\
\hline & Garlic & $80.0(63.4)^{c}$ & $100.0(90.0)^{\mathrm{a}}$ & $100.0(90.0)^{\mathrm{a}}$ & $100.0(90.0)^{\mathrm{a}}$ \\
\hline & Control & $0.0(2.03)^{\mathrm{i}}$ & $40.0(39.2)^{\mathrm{e}}$ & $60.0(50.8)^{c}$ & $100.0(90.0)^{\mathrm{a}}$ \\
\hline \multirow{2}{*}{$\begin{array}{l}\text { Cowpea with } \\
\text { black eye }\end{array}$} & Neem & $80.0(63.4)^{c}$ & $100.0(90.0)^{\mathrm{a}}$ & $100.0(90.0)^{\mathrm{a}}$ & $100.0(90.0)^{\mathrm{a}}$ \\
\hline & Eucalyptus & $40.0(39.2)^{\mathrm{f}}$ & $80.0(63,4)^{b}$ & $88.9(70.5)^{b}$ & $100.0(90.0)^{\mathrm{a}}$ \\
\hline $\begin{array}{l}\text { (Vigna } \\
\text { unguiculata }\end{array}$ & Nochi & $30.0(33.2)^{\mathrm{g}}$ & $66.7(54.76)^{d}$ & $100.0(90.0)^{\mathrm{a}}$ & $100.0(90.0)^{a}$ \\
\hline \multirow{3}{*}{ Var:Dhawala) } & Annona & $10.0(18.4)^{h}$ & $71.4(57.67)^{c}$ & $100.0(90.0)^{\mathrm{a}}$ & $100.0(90.0)^{\mathrm{a}}$ \\
\hline & Garlic & $80.7(63.4)^{c}$ & $100.0(90.0)^{\mathrm{a}}$ & $100.0(90.0)^{\mathrm{a}}$ & $100.0(90.0)^{\mathrm{a}}$ \\
\hline & Control & $0.0(2.03)^{i}$ & $20.0(26.6)^{f}$ & $40.0(39.2)^{\mathrm{d}}$ & $100.0(90.0)^{\mathrm{a}}$ \\
\hline \multirow{6}{*}{$\begin{array}{l}\text { Green gram } \\
\text { (Vigna } \\
\text { radiata) }\end{array}$} & Neem & $80.0(63.4)^{c}$ & $100.0(90.0)^{\mathrm{a}}$ & $100.0(90.0)^{\mathrm{a}}$ & $100.0(90.0)^{\mathrm{a}}$ \\
\hline & Eucalyptus & $60.0(50.8)^{d}$ & $60.0(50.8)^{d}$ & $90.0(71.6)^{b}$ & $100.0(90.0)^{\mathrm{a}}$ \\
\hline & Nochi & $40.0(39.2)^{\mathrm{f}}$ & $80.0(63.4)^{b}$ & $100.0(90.0)^{\mathrm{a}}$ & $100.0(90.0)^{\mathrm{a}}$ \\
\hline & Annona & $10.0(18.4)^{h}$ & $80.0(63.4)^{b}$ & $100.0(90.0)^{\mathrm{a}}$ & $100.0(90.0)^{\mathrm{a}}$ \\
\hline & Garlic & $88.9(70.5)^{b}$ & $100.0(90.0)^{\mathrm{a}}$ & $100.0(90.0)^{\mathrm{a}}$ & $100.0(90.0)^{\mathrm{a}}$ \\
\hline & Control & $10.0(18.4)^{h}$ & $60.0(50.8)^{\mathrm{e}}$ & $80.0(63.4)^{b}$ & $100.0(90.0)^{\mathrm{a}}$ \\
\hline \multirow{6}{*}{$\begin{array}{l}\text { Chick pea } \\
\text { (Cicer } \\
\text { arietinum) }\end{array}$} & Neem & $100.0(90.0)^{a}$ & $100.0(90.0)^{\mathrm{a}}$ & $100.0(90.0)^{\mathrm{a}}$ & $100.0(90.0)^{\mathrm{a}}$ \\
\hline & Eucalyptus & $100.0(90.0)^{\mathrm{a}}$ & $100.0(90.0)^{\mathrm{a}}$ & $100.0(90.0)^{\mathrm{a}}$ & $100.0(90.0)^{\mathrm{a}}$ \\
\hline & Nochi & $100.0(90.0)^{\mathrm{a}}$ & $100.0(90.0)^{\mathrm{a}}$ & $100.0(90.0)^{\mathrm{a}}$ & $100.0(90.0)^{a}$ \\
\hline & Annona & $100.0(90.0)^{\mathrm{a}}$ & $100.0(90.0)^{\mathrm{a}}$ & $100.0(90.0)^{\mathrm{a}}$ & $100.0(90.0)^{\mathrm{a}}$ \\
\hline & Garlic & $100.0(90.0)^{\mathrm{a}}$ & $100.0(90.0)^{\mathrm{a}}$ & $100.0(90.0)^{\mathrm{a}}$ & $100.0(90.0)^{\mathrm{a}}$ \\
\hline & Control & $90.0(71.6)^{b}$ & $100.0(90.0)^{\mathrm{a}}$ & $100.0(90.0)^{\mathrm{a}}$ & $100.0(90.0)^{\mathrm{a}}$ \\
\hline
\end{tabular}




\begin{tabular}{lccc}
\hline CV \% & 5.15 & 21.76 & 2.64 \\
CD $(0.05)$ & & & \\
Hosts & 2.25 & 7.01 & 0.51 \\
Treatments & 2.76 & 8.59 & 0.63 \\
Interaction & 5.51 & 17.18 & 1.26 \\
\hline
\end{tabular}

*Values are mean of three replications.

Values in parentheses are arcsine and square root $(\sqrt{ }(X+0.5))$ transformations.

In each column, means with similar alphabets do not vary significantly at $\mathrm{P}=0.05$ and $\mathrm{P}=0.01$ by DMRT.

CV - Coefficient of Variation

CD - Critical Difference

A study on certain selected botanicals as protectants of cowpea bruchids evidenced the superiority of garlic with $81.2 \%$ mortality among the treated botanicals viz., Curcuma longa, Ficus exasperate, Garcinia kola, Zingiber officinale and Z. officinale oil [7]. In addition, the bruchid development had been suppressed by garlic oil applied on cowpea grains [27] whereas oviposition of C. maculatus had significantly reduced in chickpea seeds when it was treated with garlic clove powder [28]. Further, a study reported that garlic was second best botanical due to the presence of diallyl sulphate, which has high fumigant action [29].

Study has proved that azedirachtin from neem plant has a deterrent, antifeedant, growth disrupting, ant ovipositional and fecundity reducing properties on a range of insects [30]. The potential of botanicals such as leaf powder of Tephrosia vogelii, the combination of neem and T. vogelii and tobacco snuff as significantly excellent measures in controlling the beetles and thus recommended as protectant of grains used for both food and seed purposes [9].

Further, the neem leaf powder is identified as effective protects of black gram, pigeon pea and green gram seeds, against $C$. chinensis with maximum adult mortality [31,32,33,34]. Meanwhile a study in India on the insecticidal action of nine plant species such as neem, garlic, eucalyptus, pongam, tulsi, custard apple, mint, ardusi and kalmegh against $C$. chinensis in black gram showed the significant role of neem leaf powder in controlling the C. chinensis followed by garlic bulb powder where acceptable efficacy has been exhibited by eucalyptus, pongam, tulsi and custard apple leaf powder [31]. However, the botanicals, mint, ardusi and kalmegh showed less effective against infesting black gram [31]. 


\section{Number of damaged seeds}

A significant difference $(\mathrm{p}<0.05)$ was found between the numbers of damaged seeds in different treatments when compared with the control (Table 2). The zero seed damage was observed in all hosts sprayed with neem and garlic especially after 14 days of $1^{\text {st }}$ spray except chickpea, which was not selected as host by bruchid beetles during the study period. The seed damage was visible in grains treated with other treatments viz., eucalyptus, nochi, annona and untreated control from $14^{\text {th }}$ day onwards.

The reference studies revealed that plant products significantly reduced the number of eggs laid by cowpea weevils on the grains and a significant reduction in the exit holes was exhibited on the garlic and chilies treated grains compared with the peppermint and untreated control treatments [24]. However, the authors stated a comparable reduction by the peppermint than the untreated control in the number of exit holes. Neem leaf powder was the most effective grain protectant in suppressing the population of pulse beetle in grains [35]. The same botanical was also registered earlier as superior in soybean and cowpea [36]. 
Table 2: Number of damaged grains in different host grains treated with different botanical pesticides by the infestation of Callosobruchus maculatus

\begin{tabular}{|c|c|c|c|c|c|c|c|c|c|c|c|c|c|c|c|c|}
\hline \multirow{3}{*}{ Treatments } & \multicolumn{4}{|c|}{$\begin{array}{l}\text { Red Cowpea (Vigna unguiculata } \\
\text { Var: Waruni) }\end{array}$} & \multicolumn{4}{|c|}{$\begin{array}{l}\text { (Vigna unguiculata } \\
\text { Var:Dhawala) }\end{array}$} & \multicolumn{4}{|c|}{ Green gram (Vigna radiata) } & \multicolumn{4}{|c|}{ Chick pea (Cicer arietinum) } \\
\hline & $1^{\text {st }}$ Spra & & $2^{\text {nd }}$ Spra & & $1^{\text {st }} \mathrm{Spr}$ & & $2^{\text {nd }} \mathrm{Spr}$ & & $1^{\text {st }} \mathrm{Spr}$ & & $2^{\text {nd }} \mathrm{Spr}$ & & $\mathbf{1}^{\text {st }}$ Spra & & $2^{\text {nd }} \mathrm{Spr}$ & \\
\hline & $\begin{array}{l}\text { After } 7^{\text {th }} \\
\text { day }\end{array}$ & $\begin{array}{l}\text { after14 } \\
\text { day }\end{array}$ & $\begin{array}{l}\text { after } 7^{\text {th }} \\
\text { day }\end{array}$ & $\begin{array}{l}\text { After14 }^{\text {th }} \\
\text { day }\end{array}$ & $\begin{array}{l}\text { after }^{\text {th }} \\
\text { day }\end{array}$ & $\begin{array}{l}\text { after14 } \\
\text { day }\end{array}$ & $\begin{array}{l}\text { after }{ }^{\text {th }} \\
\text { day }\end{array}$ & $\begin{array}{l}\text { after14 } \\
\text { day }\end{array}$ & $\begin{array}{l}\text { after } 7^{\text {th }} \\
\text { day }\end{array}$ & $\begin{array}{l}\text { after14 } \\
\text { day }\end{array}$ & $\begin{array}{l}\text { after } 7^{\text {th }} \\
\text { day }\end{array}$ & $\begin{array}{l}\text { after14 } \\
\text { day }\end{array}$ & $\begin{array}{l}\text { after } 7^{\text {th }} \\
\text { day }\end{array}$ & $\begin{array}{l}\text { after14 } \\
\text { day }\end{array}$ & $\begin{array}{l}\text { after }^{\text {th }} \\
\text { day }\end{array}$ & $\begin{array}{l}\text { after14 }^{\text {th }} \\
\text { day }\end{array}$ \\
\hline Neem & $0.00^{\mathrm{a}}$ & $0.00^{\mathrm{a}}$ & $0.00^{\mathrm{a}}$ & $0.00^{\mathrm{a}}$ & $0.00^{\mathrm{a}}$ & $0.00^{\mathrm{a}}$ & $0.00^{\mathrm{a}}$ & $0.00^{\mathrm{a}}$ & $0.00^{\mathrm{a}}$ & $0.00^{\mathrm{a}}$ & $0.00^{\mathrm{a}}$ & $0.00^{\mathrm{a}}$ & $0.00^{\mathrm{a}}$ & $0.00^{\mathrm{a}}$ & $0.00^{\mathrm{a}}$ & $0.00^{\mathrm{a}}$ \\
\hline Eucalyptus & $0.00^{\mathrm{a}}$ & $10.00^{c}$ & $12.00^{\mathrm{c}}$ & $0.00^{\mathrm{a}}$ & $0.00^{\mathrm{a}}$ & $8.00^{\mathrm{c}}$ & $18.00^{\mathrm{d}}$ & $46.00^{\mathrm{d}}$ & $0.00^{\mathrm{a}}$ & $9.00^{\mathrm{b}}$ & $12.00^{\mathrm{b}}$ & $12.00^{\mathrm{b}}$ & $0.00^{\mathrm{a}}$ & $0.00^{\mathrm{a}}$ & $0.00^{\mathrm{a}}$ & $0.00^{\mathrm{a}}$ \\
\hline Nochi & $0.00^{\mathrm{a}}$ & $2.00^{b}$ & $2.00^{\mathrm{b}}$ & $2.00^{\mathrm{b}}$ & $0.00^{\mathrm{a}}$ & $8.00^{c}$ & $12.00^{\mathrm{c}}$ & $12.00^{\mathrm{c}}$ & $0.00^{\mathrm{a}}$ & $0.00^{\mathrm{a}}$ & $0.00^{\mathrm{a}}$ & $0.00^{\mathrm{a}}$ & $0.00^{\text {a }}$ & $0.00^{\mathrm{a}}$ & $0.00^{\mathrm{a}}$ & $0.00^{\mathrm{a}}$ \\
\hline Annona & $0.00^{\mathrm{a}}$ & $12.00^{\mathrm{cd}}$ & $22.00^{\mathrm{d}}$ & $22.00^{\mathrm{c}}$ & $0.00^{\mathrm{a}}$ & $5.00^{\mathrm{b}}$ & $7.00^{b}$ & $7.00^{\mathrm{b}}$ & $0.00^{\mathrm{a}}$ & $0.00^{\mathrm{a}}$ & $0.00^{\mathrm{a}}$ & $0.00^{\mathrm{a}}$ & $0.00^{\mathrm{a}}$ & $0.00^{\mathrm{a}}$ & $0.00^{\mathrm{a}}$ & $0.00^{\mathrm{a}}$ \\
\hline Garlic & $0.00^{\mathrm{a}}$ & $0.00^{\mathrm{a}}$ & $0.00^{\mathrm{a}}$ & $0.00^{\mathrm{a}}$ & $0.00^{\mathrm{a}}$ & $0.00^{\mathrm{a}}$ & $0.00^{\mathrm{a}}$ & $0.00^{\mathrm{a}}$ & $0.00^{\mathrm{a}}$ & $0.00^{\mathrm{a}}$ & $0.00^{\mathrm{a}}$ & $0.00^{\mathrm{a}}$ & $0.00^{\mathrm{a}}$ & $0.00^{\mathrm{a}}$ & $0.00^{\mathrm{a}}$ & $0.00^{\mathrm{a}}$ \\
\hline Control & $0.00^{\mathrm{a}}$ & $20.00^{\mathrm{d}}$ & $41.00^{\mathrm{e}}$ & $68.00^{\mathrm{d}}$ & $0.00^{\mathrm{a}}$ & $10.00^{\mathrm{d}}$ & $38.00^{\mathrm{e}}$ & $80.00^{\mathrm{e}}$ & $0.00^{\mathrm{a}}$ & $13.00^{\mathrm{c}}$ & $43.00^{c}$ & $74.00^{c}$ & $0.00^{\mathrm{a}}$ & $0.00^{\mathrm{a}}$ & $0.00^{\mathrm{a}}$ & $0.00^{\mathrm{a}}$ \\
\hline
\end{tabular}




\subsection{Conclusion}

The study stated that chickpea (Cicer arietinum) was a non-host of Cowpea bruchid, Callosobruchus maculatus as the grain was not preferred by the bruchids.

The application of neem $10 \%$ (Azadirachta indicia) and garlic $10 \%$ (Allium sativum) would be effective treatments with respect to the mortality of Callosobruchus maculatus on stored grains; Red Cowpea (Vigna unguiculata var. Waruni), Cowpea with black eye (Vigna unguiculata var. Dhawala) and Green gram (Vigna radiate). Nochi $10 \%$ (Vitex negundo), eucalyptus $10 \%$ (Eucalyptus globulus) and annona $10 \%$ (Annona squamosa) also could be considered as potential plant extracts against Cowpea weevil, Callosobruchus maculatus.

\section{References}

[1] Fekadu, G., Waktole, S., Dante, R., and Santiago. (2012). Evaluation of plant powders and cooking oils against maize weevil, Sitophilus zeamais M. (Coleoptera: Curculionidae) under laboratory conditions. Molecular Entomology, 3(2): 4-14.

[2] Phillips, RD., and Dedeh, SS. 2003. Developing nutritional and economic value added food product from cowpea. http;//www.isp.msu.edu/crsp/Final Report. PDF. Downloaded 01.01.2018.

[3] Bekele, AJ., Ofori, DO., and Hassanali, A. (1995). Products derived from the leaves of Ocimum kilimandscharicum (Labiatae) as post-harvest grain protectants against the infestation of three major stored product insect pests. Bulletin of Entomological Research. 85: 361-367.

[4] Udo IO., and Harry GI. (2013). Effect of groundnut oil in protecting stored cowpea, Vigna unguiculata from attack by cowpea Callosobruchus maculatus. Journal of Biology Agriculture and Health Care. 3 (1): 89-92.

[5] Cope JM., and Fox CF. (2003). Oviposition decision in the seed beetle, Callosobruchus maculates (Coleoptera: Bruchidae) effects of seed size on super parasitism. Journal of Stored Product Research. 39: 355-365. 
[6] Felicia Nkechi Ekeh, lkechukwu Eugene Onah, Chinedu ifeanyi Atama, Njoku ivoke, and Joseph Effiong Eyo. (2013). African Journal of Biotechnology. 12(12): 1384-1391.

[7] Asawalam, EF., and Anaeto, CG.(2014).Laboratory evaluation of five botanicals as protectants against cowpea bruchid Callosobruchus maculates $\mathrm{F}$. (Coleoptera: Bruchidae) on stored cowpea. Net journals Advancement in Medicinal Plants Research. 2(2): 41-46.

[8] Rahman, A., and Talukder, FA. (2006). Bio efficacy of some plant derivatives that protect grains against the pulse beetle, Callosobruchus maculates. Journal of Insect Science. 6(3): 1-10.

[9] Shazia, OWM., Reuben, Minza, Masunga., Rhodes, Makundi., Robert, N, Misangu., Bukheti, Kilonzo., Maulid, Mwatawala., Herman, F, Lyimo., Christine, G, Ishengoma., Dastun, G., and Loth, S, Mulungu. (2006). Control of cowpea weevil (Callosobruchus maculatus L.) in Stored Cowpea (Vigna unguiculatus L.) Grains using Botanicals. Asian Journal of Plant Science. 5(1): 91-97.

[10] Chaubey, MK. (2008). Fumigant toxicity of essential oils from some common spices against Pulse beetle, Callosobruchus chinensis (Coleoptera: Bruchidae). Journal of Oleo Science.57: 171-179.

[11] Park, C., Kim, SI., and AhnYJ. (2003). Insecticidal activity of asarones identified in Acorus gramineus rhizome against three coleopteran storedproduct insects. Journal of Stored Products Research. 39: 333-342.

[12] Maribet, L., Parugrug., and Aurea, C, Roxas. (2008). Insecticidal action of five plants against maize weevil, Sitophilus zeamais Motsch. (Coleoptera: Curculionidae), Department of Crop Production /Research Office, Central Luzon State University, Science City of Munoz, Nueva Ecija, Philippines, KMITL Science Technical Journal. 8 (1): 24-38. 
[13] Regnault-Roger, C., Vincent, C., \& Arnason, J, T. (2012). Essential oils in insect control: Low-risk products in a high-stakes world. Annual Review of Entomology, 57: 405-424.

[14] , RC., Jilani, G., and Kareem, AA. (1989). Effects of neem on stored grain insects in Jacobson (ed.) Forum on phytochemical pesticides. The neem tree. Boca Raton, Florida: CRC Press. 1: 97-111.

[15] Balachandra, B, A, H, E., and Pathirathna, P, Uand, Paranagama, P, A. (2012). Control of stored grain pest, Callosobruchus maculatus (F.) (Coleoptera: Bruchidae) using the essential oil isolated from Plectranthus zeylanicus. Natural Product Research. 26(23): 2219-2222.

[16] Gayatri Nahak., and Rajani Kanta Sahu. (2017). Article of Bio-controlling Effect of Leaf Extract of Tagetes patula L. (Marigold) on Growth Parameters and Diseases of Tomato. Pakistan Journal of Biological Sciences. 20(1): 1219.

[17] Anonymous. (2010). Botanical alternatives in plant protection. Asian NGO Coalition for agrarian reforms and rural development. Philippines.

[18] Suleria, HAR., Butt, MS., Anjum, FM., Saeed, F., Battol, R., and Ahmad, AN. (2012). Aqueous garlic extract and its phytochemical profile; special reference to antioxidant status. International Journal of Food Sciences and Nutrition. 63(4): 431- 439.

[19] Abdullah, Ahmady., Magdi, AA., Mousa., and Ahmed, A, Zaitoun. (2017). Efficacy of Some Botanical Oils against Stored-product Pest Cowpea Beetle, (Callosobruchus chinensis (F.) (Coleopte: Bruchidae). International Journal of Zoology Studies. 2(1): 05-09.

[20] Muhammad, Sarwar. (2012). Assessment of resistance to the attack of bean beetle Callosobruchus maculates (Fabricuus) in chickpea genotypes based on various parameters during storage. Songklanakrin Journal of Science and Technology. 34(3): 287-291. 
[21] Shafique, M., and Ahmad, M. (2005). Chickpea Grains Resistance to Pulse Beetle, Callosobruchus analis (F.) (Coleoptera: Bruchidae). Pakistan Journal of Zoology. 37 (2): 123-126.

[22] Nwanze, KF., Horbe, E., and Pitts, CW. (1975). Evidence for ovipositional preference of Callosobruchus maculates for cowpea varieties. Environmental entomology. 4(3): 409-412.

[23] Boeke, SJ., Dicke, M., van, Huis, A., and van, Loon, JJA. (2004). Host preference of Callosobruchus maculates; a comparison of life history characteristic for three strains of beetle on two varieties of cowpea. Journal of Entomology and Nematology. 28: 449-456.

[24] Bamphitlhi, Tiroesele., Kesegofetse, Thomas., and Seipati, Seketeme. (2015). Control of Cowpea Weevil, Callosobruchus maculates (Coleoptera: Bruchidae), Using Natural Plant Products.Insect. 6(1): 77-84.

[25] Onu, I., and Aliyu, M. (1995). Evaluation of powdered fruits of four peppers (Capsicum sp) for the control of Callosobruchus maculates on stored cowpea seeds. International Journal of Pest Management. 41(3): 143-145.

[26] Oparaeke, AM. (1997). Evaluation of comparative efficacy of some plant powders for the control of Callosobruchus maculates F. (Coleoptera; Bruchidae) on stored cowpea. M.Sc. Thesis, Ahmadu Bello University, Zaria, Nigeria. 105 pp.

[27] Dauda, Z., Maina, YT., and Richard, BI. (2012). Insecticidal activity of Garlic (Alium sativum L.) oil on Callosobruchusmaculatus (F.) in post-harvest cowpea (Vigna unguiculata (L) Walo. Journal of Biology, Agriculture and Health Care. 2(3): 29-35.

[28] Singh, R. (2011). Evaluation of some plant products for their oviposition deterrent properties against the Callosobruchus maculatus (F.) on chickpea seeds. Journal of Agricultural Technology. 7(5): 1361367.

[29] Upadhyay, RK., and Ahemad, S. (2011). Management Strategies for Control 
of Stored Grain Insect Pests in Farmer Stores and Public Ware Houses. World Journal of Agricultural Sciences. 7(5): 527-549.

[30] Schmutterer, H. (1990). Properties and potential of natural pesticides from the neem tree, Azadiracta indica. Annual Review of Entomology. 35: 271297.

[31] Suthar, MD., and Bharpoda, TM. (2016). Evaluation of botanicals against Callosobruchus chinensis Linnaeus in black gram under storage condition. Indian Journal of Agricultural Research. 50(2): 167-171.

[32] Varma, S., and Anandhi, P. (2010). Biology of pulse beetle (Callosobruchus chinensis Linn. Coleoptera: Bruchidae) and their management through botanicals on stored mung grains in Allahabad region. Legume Research - An International Journal. 33: 38-41.

[33] Tripathi, S., Sangeeta, A., and Chandralekha. (2006). Effect of neem leaf powder on infestation of the pulse beetle, Callosobruchus chinensis in stored pigeon pea (Cajanus cajan). Vegetos. 19(1, 2): 27 - 29.

[34] Hasan, M., Muhammad, S., Shahzad, S., Sajid, H., Sohail, A., and Shahid, MH. (2012). Evaluation of insecticidal potential of powders of Azadirachta indica, Momordica charentia and Allium sativum against Callosobruchus chinensis (Coleoptera: Bruchidae). Pakistan Entomologist. 34: 71-73.

[35] Devi, MB., and Devi, NV. (2013) Effect of some botanicals on adult mortality, oviposition and development of pulse beetle, Callosobruchus chinensis L. on gram. Indian Journal of Entomology. 75: 295-297.

[36] Choudhary S. (2012). Varietal susceptibility and evaluation of grain protectants against Callosobruchus chinensis Linnaeus on soybean under storage condition. M.Sc. thesis submitted to Department of Entomology, B. A. College of Agriculture, Anand Agricultural University, Anand. 